The first is found in Irenaeus III vi 4 Mass. (where the Latin Version alone is extant) 'Et ego igitur invoco te, Domine . . . qui fecisti caelum et terram, qui dominaris omnium .... per Dominum nostrum Iesum Christum dominationem quoque dona Spiritus Sancti'. The Latin words dominari, dominatio in this passage are almost certainly renderings of кuprevery and кuprórns (see the Greek and the Latin version in V ix 4). The words of Irenaeus might well have been suggested by the phrase

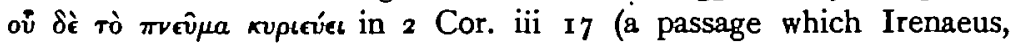
I believe, does not quote in his extant writings); but they are in themselves so natural that they do not require a Scriptural source to account - for them. The second passage is Tertullian de Baptismo iv 'Spiritus enim dominatur, caro famulatur'. Tertullian here uses the Latin

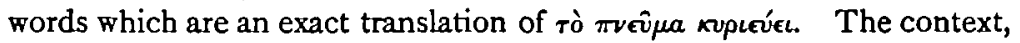
however, shews that the reference is rather to that spirit 'qui est auctor delicti'. It would be more than precarious to argue that Tertullian is unconsciously using a Scriptural phrase but giving it a new application. I conclude, therefore, that the emendation xupsevice in 2 Cor. iii 77 must be regarded as reversing a strictly 'primitive error'.

F. H. ELY.

\title{
THE CHURCHES AT WINCHESTER IN THE EARLY ELEVENTH CENTURY.
}

The Cathedral of Winchester has so large a place in my boyish recollections that it has been a special pleasure to me, when working at the early history and MSS of the Cathedral of Worcester, to find how close and intimate was the connexion between the two churches. In any Worcester kalendar of the eleventh or twelfth century we should be fairly certain to find that next in importance to the commemoration of the local saints Egwin and Oswald came the commemoration of the Winchester worthies, St Birinus, St Swithun, and St Judoc Among Archbishop Parker's MSS at Corpus Christi College, Cambridge, no. ${ }_{4} 6$ is a Winchester Pontifical of about the year 1000 which has received additions, before and after the original nucleus, made for bishop Samson a hundred years later. The MS with which I am now concerned was also written at Winchester, not very much later than the C.C. C. book, and also taken at some early date to Worcester. It is still preserved in the Worcester Chapter Library, where it bears the number F I 73: but the hand of time has dealt hardly with it, and only 30 leaves remain, 
besides two parts of leaves. What remains has been carefully mounted and beautifully bound: by the kindness of Canon J. M. Wilson, the Librarian, $I$ have been able to examine it at leisure in the Bodleian.

The greater part of the extant leaves is taken up with the Offices of Unction of the Sick, Prayers for the Dying, and Burial of the Dead. It is part of the last of these offices that I am here printing: the body of the deceased brother is taken to the surrounding churches, and a prayer is said at each. The first, with reference to the Blessed Virgin and St Benedict 'our patron', is doubtless introductory: the next two, St Michael the archangel and the Virgin Mary respectively, may also be general, or they may refer to two churches outside the monastery in some one direction. In either case the scene of the next prayer is the mother Church, mention being made of Birinus, Swithun, Ethelwold, 'and all the saints whose relics are contained in this monastery'. The three following prayers imply a church or chapel of St George, another of St Gregory, and another (a nunnery?) of St Mary and all holy virgins. After this comes the prayer ' in the church of the New Monastery', the only instance in which the locale is definitely mentioned in the rubric, though the names of the saints, St Peter, St Judoc, and St Grimbald would in any case have made the identification easy. At this point comes the Mass, and afterwards the wandering of the corpse is resumed, and the churches visited are St Thomas, St Maurice with St Pantaleon, St Michael, and St Ethelwold.

\section{TEXT (fol. 21 a)}

Post hec portetur corpus defuncti ad alias oircumstantes ecclesias cum antiphonis et psalmis atque ad singulas ponatur ecclesias - et oratione dominica cantata dicatur a sacerdote .

Et ne nos inducas $\cdot$ Requiem eternam - A porta inferi $\cdot$ Requiescat in pace . Amen .

\section{Oremus.}

Deus cui proprium est misereri semper et pa $[\mathrm{r}] \mathrm{cere}$, suscipe propitius orationem nostram, et intercedente beata Dei genitrice semperque virgine Maria et beato Benedicto patrono nostro, anime famuli tui remissionem omnium tribue peccatorum, ut quem delictorum catena constringit miseratio tue pietatis absolvat, per eum qui venturus .

Tuam Deus deposcimus.

Oratio.

Ascendant ad te Domine preces nostre, et animam famuli tui gaudia eterna suscipiant, et quem fecisti adoptionis participem, intercedente beato Michaele archangelo, iubeas hereditatis tuę consortem - per eum qui . 
Alia.

Presta quesumus omnipotens et misericors Deus - ut beata semper virgine MARIA intercedente, animam famuli in congregatione iustorum eternę beatitudinis iubeas consortem - per eum .

Alio.

Deus cuius misericordie nullus est numerus, suscipe preces nostras, et intercedentibus sanctis confessoribus tuis - BYRINO - et sUUITHUNO atque ATHELUUOLDO omnibusque sanctis quorum reliquie in hoc continentur monasterio, anime famuli tui lucis letitiam concede, atque in regione vivorum sanctorum tuorum tribue societatem - per eum .

Alio.

Propitiare Domine supplicationibus nostris, et intercedente beato GEORGIO martire tuo animam famuli tui in regione vivorum eternis gaudis iubeas sociari - per eum .

Alia.

Omnipotens sempiterne Deus - suscipere dignare preces nostras, et intercedente beato GREGORIO omnibusque sanctis confessoribus tuis, anime famuli tui pacem concede perpetuam et requiem sempiternam per eum.

Alis.

Omnipotens sempiterne Deus, cui numquam sine spe misericordie supplicatur, intercedente beata Dei genetrice semperque virgine MARIA omnibusque sanctis virginibus tuis, propitiare animę famuli tui atque eam sanctorum tuorum numero facias adgregari - per eum.

\section{Oratio in Novi Monesterii ecclesia.}

Deus venię largitor et humane salutis amator, quesumus inmensam clementiam tuam, ut intercedente beato PETRO principe apostolorum, et coapostolo eius Paulo omnibusque apostolis necnon et beatis confessoribus tuis IUDOCO atque GRIMBALDO, omnibusque sanctis in hoc venerando monasterio quiescentibus, animam famuli tui ad perpetue beatitudinis consortium pervenire concedas - per eum .

Post hec dicatur missa et post missam deportetur corpus defunoti (ad alias circum P) positas ecclesies cum antiphonis et quindecim psalmis atque orationibus.

Annue quesumus Domine ut anima famuli tui cunctorum nexibus expedita delictorum, intercedente beato тнома omnibus[que] apostolis tuis, libertatem eternorum consequatur gaudiorum - per eum .

\section{Alia.}

Deus cui proprium est misereri semper et parcere, intercedente beato MARICIO cum socii[s] suis et belato PANTALEONE cum omnibus martyri- 
bus tuis, propitiare animę famuli tui, et omnia eius peccata dimitte, ut mortis vinculis absoluta transire mereatur ad vitam - per eum .

Alis.

Presta quesumus Domine, ut intercedente beato Michaele archangelo omnibusque angelorum ordinibus atque omnium cęlestium virtutum deprecationibus, anima famuli tui omnium purgata contagiis peccatorum, indulgentiam pariter et requiem capiat sempiternam - per eum .

Alia.

Adiuva nos Domine Deus noster, et beati Atheluuoldi omniumque sanctorum confessonm tuorum precibus exoratus, animam famuli tui in beatitudine sempiternę lucis constitue - per eum .

Alia.

Miserere quesumus Domine anime famuli tui cuius sepeliendi corporis officium celebramus, et presta ut omnium sanctorum tuorum interventionibus a cunctis peccatorum absoluta contagiis, eternis paradisy restituatur gaudiis - per eum qui .

Aperite illi portas iustitie etc.

C. H. Turner.

\section{CLEMENT OF ALEXANDRIA AND ART.}

Clement's first book, the Protrepticus, consists largely of an attack on Greek image-worship, and his other works contain many references to this side of the old religions. Light is thus thrown on the view of Art held by Clement and by the Christian Church of his day. The present study is an attempt to estimate this view from an examination of all Clement's words that bear upon it. Brief reference will also be made to its historical origin, as well as to its modification by the Church in later ages.

I

Clement cannot be called an original thinker. $\mathrm{He}$ is what alone he claims to be, the exponent of a tradition which has received shape long before his time. ${ }^{1}$ Even in regard to the slighter details of interpretation

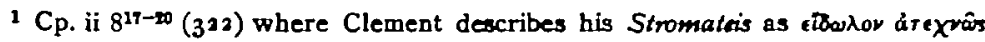

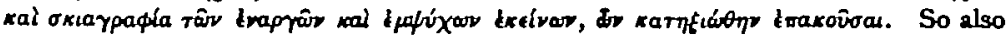

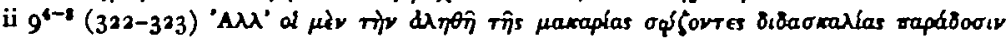

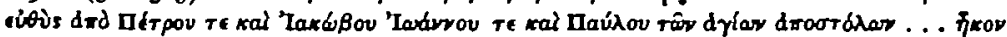

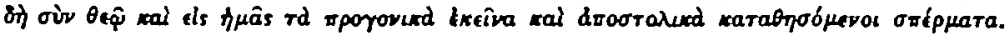

